\title{
Matrilinial System and The Activity of Women Trafficking In West Sumatera
}

\author{
Ike Revita \\ Universitas Andalas \\ Padang, Indonesia \\ revita_ike@yahoo.com
}

\author{
Rovika Trioclarise \\ Politeknik Kesehatan Kementerian \\ Kesehatan III \\ Jakarta, Indonesia
}

\author{
Fahmi Gunawan \\ Institut Agama Islam Negeri Kendari \\ Kendari, Indonesia
}

\begin{abstract}
This research is aimed at explaining the reality reflected in the phenomena of women trafficking related to matrilineal system owned by Minangkabau people in West Sumatera. The objective is to identify the factors influencing the existence of women trafficking in Minangkabau society. The research is conducted in West Sumatera (Padang, Tanah Datar, and Lima Puluh Kota). The data are collected by interviewing the society. Any documents related to women trafficking and some other related references are used as the supporting information for the analysis. Having analyzed the data, it is found that there are four factors influencing the existence of women trafficking in West Sumatera namely (1) the shifting of interpretation on local wisdom; (2) no regeneration of Minangkabau tradition; (3) rapid flow of technology; and (4) shifting of life style.
\end{abstract}

Keywords-Matrilineal System; Women Trafficking; West Sumatera

\section{INTRODUCTION}

Human trafficking is one transnational crime that organized and almost worldwide. This crime is neatly organized and hard to detect by law enforcement. Women trafficking is a kind of activity in which women are not regarded as human [1]. The women are treated as stuff in which they can be sold and bought. Victims of trafficking women are also victims of sexual slavery as well suffered tremendous violence. Women as victims of crime suffer physical and emotional injuries.

Indonesia's geographical conditions bordering with various countries facilitate the occurrence of woman trafficking. In addition, the social conditions of society such as poverty and lack of education leads women to easily believe in the temptation of criminals.

This reality occurs around us since women trafficking is like the peak of ice-mountain. One of these phenomena is found in West Sumatera.

Minangkabau ethnic (commonly named Minangkabau people) is well-known with its matrilineal system [2]. The matrilineal system means group adhering to a kinship system in which lineal descent is traced through maternal instead of paternal lines. This system is rarely found in this world. There are some other ethnics like Champ in
Vietnam or Tamils in Srilanka having this system, but Minangkabau is much more complicated than others [3].

Even though the descent is through the female line, the female does not mean dominate all aspects of social life. Female are put in a certain position which gives great contribution to the society. This is in line with wise words in Minangkabau language 'Anak dipangku, kamanakan dibimbiang' 'Children are lapped, and nephews are guided.' This implies that everybody in Minangkabau society cares each other.

This fact is in contradictory with the activities of women trafficking. This phenomenon occurs in West Sumatera with its fame as the largest and strongest matrilineal system. This inhuman action is due to several factors. Many people have conducted the research about women trafficking with various terms. Trafficking in women [4], women trafficking [5], [6], violence against women [7] trafficking in human beings [8]. Moreover, the more accurate terminology related to human trafficking is also used such as child trafficking [9], that finally becomes the forced labor [10].

The previous related studies indicate that no research yet relate the phenomena of women trafficking with the social and cultural situation. That Minangkabau is identical with its philosophy adat basan di syarak, syarak basan di kitabullah (the culture is based on sharia', sharia' is based on Quran) is contradictory with the reality that women trafficking happens there. Many women are trapped in this situation. Thus, this research is of great urgent and important being conducted.

\section{METHOD}

This research is qualitatively which focused on the interaction within the society in Padang City, Tanah Datar District, and Lima Puluh Kota District in West Sumatera. Data collection was carried by depth interviews, note-taking, and recording [11]. The number of respondent is 30 comprises, ten from the society, six from the government, two from NGO, three from the traditional leader, three from a religious leader, three from the victims, two from the panders, and one from psychologists. The analysis is conducted based on the concept of women trafficking proposed by Wheaton, et al. and the activities of women trafficking in West Sumatera[12]. 


\section{RESULTS}

Based on the research, the existence of matrilineal and its kinship system in West Sumatera does not prevent the spread of the trading of women yet. Some external factors play an important role in enhancing the smoothness of this women trafficking [13].

Firstly is the shifting of interpretation on local wisdom. It can be defined as the value that is considered good and inherited for generations [14]. The local wisdom is commonly implemented by the peoples concerned as a result of the interaction between man and his environment [15]. This implementation is then reflected by the way they live, interact, and behave.

Like the society that put the women in upright position, Minangkabau women are designed to be robust and do not depend fully on men. Even though they have a spouse (husband), it does not mean that they cannot do anything. The treasure in Minangkabau culture is inherited to daughter. This implies that materially, Minangkabau women are rich. Thus, they are not supposed to worry about the finance. Unfortunately, this tradition is not well-kept, in the sense that, Minangkabau women do not wisely manage their treasure. This is due to their understanding that husband must support all they need. This way of thinking is followed by around $23 \%$ Minangkabau women (mostly in a suburban area). Consequently, as they need more money and husband cannot support more, they will accept any work as long as it can fulfill their need.

Secondly is no regeneration of Minangkabau tradition. The way of instantly think to make the tradition of Minangkabau with its indirectness and implicitness is regarded useless. Most people in Minangkabau interpret that this un-efficient and uneffective. Being direct and straight forward Grice is more preferable [16]. Since the implicit and indirect way of behaving, including in communication, is not regenerated as the panders of women trafficking act, they fail to gain the meaning well. The panders just want to deceive them through formal communication, but they assume as it is. There is around $17 \%$ of this factor found in the women trafficking activities.

Thirdly is an unprevented flow of technology. The development of technology spread quickly all over the world [17]. This also happens in West Sumatera. Many people use technology as a means to see other parts of the world. They can easily get information via the sophisticated tools which sometimes less of the filter. In other words, most of the women fully adopt what they see. Around $27 \%$ of Minangkabau women use technology in their lives. Unfortunately, they forget the norm implemented in their environment. Consequently, they become the victims of women trafficking.

The last one is the shifting of lifestyle. This factor is the further effect of the flow of technology. Lack of knowledge makes $33 \%$ of Minangkabau women use the technology improperly [18]. One of the effects is they imitate what they see. They are also easily influenced by the environment. The attitude of having a consumptive lifestyle which is not supported by enough money is leading them to come to the world of trafficking [19].

The recapitulation factors human trafficking protection with matrilineal are shows in Table 1.

TABLE I. RECAPITULATION FACTORS

\begin{tabular}{|l|l|}
\hline \multicolumn{1}{|c|}{ Factors } & \multicolumn{1}{c|}{ Matrilineal } \\
\hline Interpretation of local wisdom & The value of family \\
\hline $\begin{array}{l}\text { Regenaration of Minangkabau } \\
\text { tradition }\end{array}$ & $\begin{array}{l}\text { The role of women in Minangkabau } \\
\text { kinship }\end{array}$ \\
\hline Unprevented flow of technology & Knowledge to select information \\
\hline Shifting of lifestyle & Moral strength \\
\hline
\end{tabular}

\section{DISCUSSION}

The activity of women trafficking is like the ice peak in which the top looks small, but the foot is gigantic. As the 3rd biggest illegal business in the world, the women trafficking has very high profit with low risk [20]. Many countries in the world have become the target and the main source of women trafficking including Indonesia [21]. Statistically, West Sumatera has not had a record yet on women trafficking. In fact, many Minangkabau women became the victims and the target of this trafficking [18]. This is caused by several factors. One of them is the ability of the panders in persuading the victims to be.

The ability is in line with the strategy that the panders used. For example is by having very polite way of communication [22]. This polite way is a kind of rhetorical competence to save one's face in communication [23]. Minangkabau is well known as the Society which maintains the aspect of politeness. This community names it as nan ampek 'the four' which is raso, pareso, malu, sopan 'sense/feeling, rechecking, shyness, politeness.' The four must be in line each other. Otherwise, they are not regarded as a Minangkabau.

The disability to prevent the activity of women trafficking in West Sumatera creates the flow of the number of Minangkabau women become the victims of trafficking. Unfortunately, there is no the exact number recorded. Many things are hidden. This is also related to the rule in Minangkabau in which the uncle has a responsibility toward his nephew. However, this rule has diverse. The role of the uncles stays far away from what he must be. The situation is getting worse as no regeneration to the youth.

The youth has no one to be imitated. They have no guidance to follow the appropriate rule. They just get the new information from media through sophisticated technology. This information then slowly change the way they view reality. The norm as their rule and frame to behave is then crashed. The interpretation comes up regarding tradition as the handicap to move on, and the lifestyle changes.

The limitation of competence in education, economy, and knowledge but having good looking make many women are potential to be the victims. By persuading and coaxing, these women then be trapped in the circle of trafficking. 


\section{CONCLUSION}

Women trafficking cannot be prevented as long as no comprehensive action. The society and the government must hand in hand cooperate to exterminate this inhuman action. As the whole lines have similar willingness to stop and prevent this women trafficking, no more women will be stuck here. Women are future of the society. Women are the country pole. As the women are right, the country will be safe. Women are the agent of change. They give birth the babies of the future. How can they give good baby as they are not good, not healthy, and in under pressure situation? Women must be protected. The women must be saved and no more trafficking toward women.

\section{References}

[1] A. A. Aronowitz, 'Smuggling and trafficking in human beings: the phenomenon, the markets that drive it and the organisations that promote it', Eur. J. Crim. policy Res., vol. 9, no. 2, pp. 163-195, 2001.

[2] E. Schrijvers, J., \& Postel-Coster, 'Minangkabau women: Change in a matrilineal society', Archipel1, vol. 3, no. 1, pp. 79-103, 1977.

[3] M. S. Sait, 'Women's Property Rights in Muslim Matrilineal Communities', Islam. St. Pr. Int'l L9, vol. 1, 2013.

[4] B. Sullivan, 'Trafficking in women', Int. Fem. J. Polit., vol. 5, no. 1, pp. 67-91, 2003.

[5] A. Farrel, 'Hidden Victims of Human Trafficking', in NIJ Conference, 2012.

[6] A. P. Giardino and R. D. Sanborn, 'Human Trafficking: Awareness , Data and Policy', J. Appl. Res. Child. Informing Policy Child. Risk, vol. 2, no. 1, 2011

[7] S. R. Kamazima, M. J. Ezekiel, M. R. Kazaura, and B. Fimbo, 'Understanding the link between trafficking in persons and HIV and AIDS risk in Tanzania', Tanzan. J. Health Res., vol. 14, no. 1, pp. 1-12, 2012.
[8] V. Ruggiero, 'Trafficking in human beings: slaves in contemporary Europe', Int. J. Sociol. Law, vol. 25, no. 3, pp. 231-244, 1997.

[9] Y. Rafferty, 'Children for sale: Child trafficking in Southeast Asia', Child Abus. Rev., vol. 16, no. 6, pp. 401-422, 2007.

[10] S. C. Inglis, 'Expanding international and national protections against trafficking for forced labor using a human rights framework', Buff. Hum. Rts. L. Rev, vol. 7, no. 55, 2001.

[11] K. J. Sturges, J. E., \& Hanrahan, 'Comparing telephone and face-to-face qualitative interviewing: a research note.', Qual. Res., vol. 4, no. 1, pp. 107-118, 2004.

[12] E. M. Wheaton, E. J. Schauer, and T. V. Galli, 'Economics of human trafficking', Int. Migr., vol. 48, no. 4, pp. 114-141, 2010.

[13] L. Murphy, How Advocate Fighting Human Trafficking Can Overcome Divisions and Build Momentum. US: Colombia Univ. Press, 2013.

[14] M. R. Mungmachon, 'Knowledge and local wisdom: community treasure', Int. J. Humanit. Soc. Sci., vol. 2, no. 13, pp. 174-181, 2012.

[15] S. V. Steffensen and A. Fill, 'Ecolinguistics: The state of the art and future horizons', Lang. Sci., vol. 41, pp. 6-25, 2014.

[16] H. P. Grice, 'Logic and Conversation.pdf', Syntax and Semantics, Vol 3. pp. 41-58, 1975.

[17] D. Cohen, H., Keller, S., \& Streeter, 'The transfer of technology from research to development', Res. Manage., vol. 22, no. 3, pp. 11-17, 1979.

[18] T. Revita, Ike and Rovika, 'Medical Perlocutionary Effect of the Victims of Women Trafficking', in Seminar Nasional Pragmatik, Semiotik, dan Kebudayaan, 2016.

[19] R. Rosenberg, Trafficking in Women and Children in Indonesia. Jakarta: Usaid, 2007.

[20] S. Kara, 'Designing More Effective Laws Against Human Trafficking', J. Int. Hum. Rights, vol. 9, no. 2, pp. 123-147, 2011.

[21] Muflichah; Wintoro; Rahadi Wesi, 'Trafficking: Suatu Studi Tentang Perdagangan Perempuan dari Aspek Sosial, Budaya, Ekonomi di Kabupaten Banyumas', J. Din. Huk., vol. 9, no. 1, pp. 125-134, 2009.

[22] I. Revita, R. Trioclarise, and N. Anggreiny, 'Politeness Strategies of The Panders in Women Trafficking', Bul. Al-Turas, vol. XXIII, no. 1, pp. 191-210, 2017.

[23] P. Brown and S. C. Levinson, 'Politeness: Some Eniversals in language Usage', The Discourse Reader. pp. 311-323, 2014. 